\title{
Mannose 6-phosphate potentiates insulin-like growth factor II effects in cultured human neuroblastoma cells
}

\author{
Eva L. Feldman and Ann E. Randolph \\ University of Michigan, Neuroscience Laboratory, Ann Arbor, MI 48104-1687 (U.S.A.)
}

(Accepted 28 May 1991)

\begin{abstract}
Key words: Insulin-like growth factor I; Insulin-like growth factor II; Insulin-like growth factor II receptor; Mannose 6-phosphate;
\end{abstract} Neuroblastoma; Mitogenesis; Neurite outgrowth

\begin{abstract}
Insulin-like growth factor II (IGF-II) and mannose 6-phosphate (man-6-P) bind to distinct sites on the same receptor ${ }^{4,16,20}$. In the present study, we examined the effects of man-6-P on the growth promoting effects of IGF-II on SH-SY5Y cultured human neuroblastoma cells. Man-6-P alone increased cell number and neurite outgrowth by approximately $50 \%$; as previously observed ${ }^{12,18,27,30}$, IGF-II increased cell number and neurite outgrowth by approximately 110 and 30\%, respectively. However, when cells were grown in the presence of both ligands, cell number increased by $330 \%$ and neurite outgrowth by $130 \%$. These results suggest that man-6-P can potentiate the known growth promoting effects of IGF-II on human neuroblastoma cells. Furthermore, they indicate that the IGF-II/man-6-P receptor may serve as a means of integrating distinct growth promoting signals in neuronal cells.
\end{abstract}

\section{INTRODUCTION}

Insulin-like growth factor-I and -II (IGF-I and IGFII) are peptides with both growth-promoting and insulin-like activity ${ }^{6,9,34}$. In vitro, both IGF-I and IGF-II are mitogenic for neurons ${ }^{10,12,18}$ and stimulate neuritic outgrowth $^{19,27,29,30}$. The actions of the IGF peptides are mediated by specific cell surface receptors ${ }^{6,7,9,34}$. The type I IGF receptor is structurally and functionally similar to the insulin receptor ${ }^{34}$ and receptor binding results in autophosphorylation of tyrosine residues. The type II IGF receptor, unrelated to the IGF-I and insulin receptor, is identical to the mannose 6-phosphate (man-6-P) receptor $^{1,15,16,20}$. The IGF-II/man-6-P receptor, with separate ${ }^{4}$ but cooperative binding sites for both IGF-II and man6- $\mathrm{P}^{33}$, mediates intracellular and extracellular targeting of lysosomal enzymes via the man-6-P binding site ${ }^{8}$. IGF-II, coupling to its distinct site on the IGF-II/man6-P receptor, can stimulate DNA synthesis ${ }^{3}$, increase amino acid uptake $e^{2,13}$, enhance $\mathrm{Ca}^{2+}$ influx ${ }^{22}$ and activate $G$ proteins ${ }^{23,24}$. The biological significance of one receptor capable of binding both IGF-II and man-6-P remains uncertain. Recent work, however, suggests the IGF-II/man-6-P may play a role in integrating multiple growth-promoting signals. Secreted man-6-P containing proteins, including transforming growth factor- $\beta 1$ pre- cursor $^{26}$, proliferin ${ }^{14}$ and cathepsin $\mathrm{D}^{17}$ can bind the man-6-P site of the IGF-II/man-6-P receptor and serve as autocrine growth factors ${ }^{17}$.

In the present study, we examined the effects of man6-P in conjuction with IGF-II on SH-SY5Y human neuroblastoma cell mitogenesis and neuritic outgrowth. This cell line serves as a good model for the growth-promoting effects of the insulin-like growth factors. Both IGF-I and IGF-II receptors are present on SH-SY5Y cells ${ }^{28}$, which are stimulated to undergo mitogenesis ${ }^{12,18}$ as well as vigorous neuritic outgrowth ${ }^{19,27,29,30}$ by both peptides. We report that man-6-P alone can enhance both neuroblastoma mitogenesis and neuritic outgrowth, and in the presence of IGF-II, these effects are potentiated. We speculate that man-6-P-containing proteins may act in an autocrine or paracrine fashion, in concert with IGF-II, to regulate neuronal growth.

\section{MATERIALS AND METHODS}

\section{Materials}

Human recombinant IGF-II (Bachem, Torrance, CA) was dissolved in $10 \mathrm{mM}$ acetic acid and stored at $-20^{\circ} \mathrm{C}$. D-Man-6-P was purchased from Sigma Chemicals, St. Louis, MO.

\section{Cell culture}

Human SH-SY5Y neuroblastoma cells were kindly provided by Dr. Stephen Fisher, University of Michigan Medical Center. Cells 
were maintained in plastic tissue culture flasks in Dulbecco's Modified Eagle's Medium (DMEM) supplemented with $10 \%$ calf serum (CS). Cells were maintained in an atmosphere of $5 \% \mathrm{CO}_{2}$ and $95 \%$ humidified air
Growth studies ${ }^{3.5}$

To determine cell doubling, $3 \times 10^{5}$ cells were seeded in $3.5 \mathrm{~cm}$ culture wells in DMEM supplemented with $2 \mathrm{mg} / \mathrm{ml}$ glucose and $10 \% \mathrm{CS}$. After 3 days in culture, cells were rinsed with $1 \mathrm{ml}$ of warm serum-free DMEM before adding $3 \mathrm{ml}$ warm DMEM con-
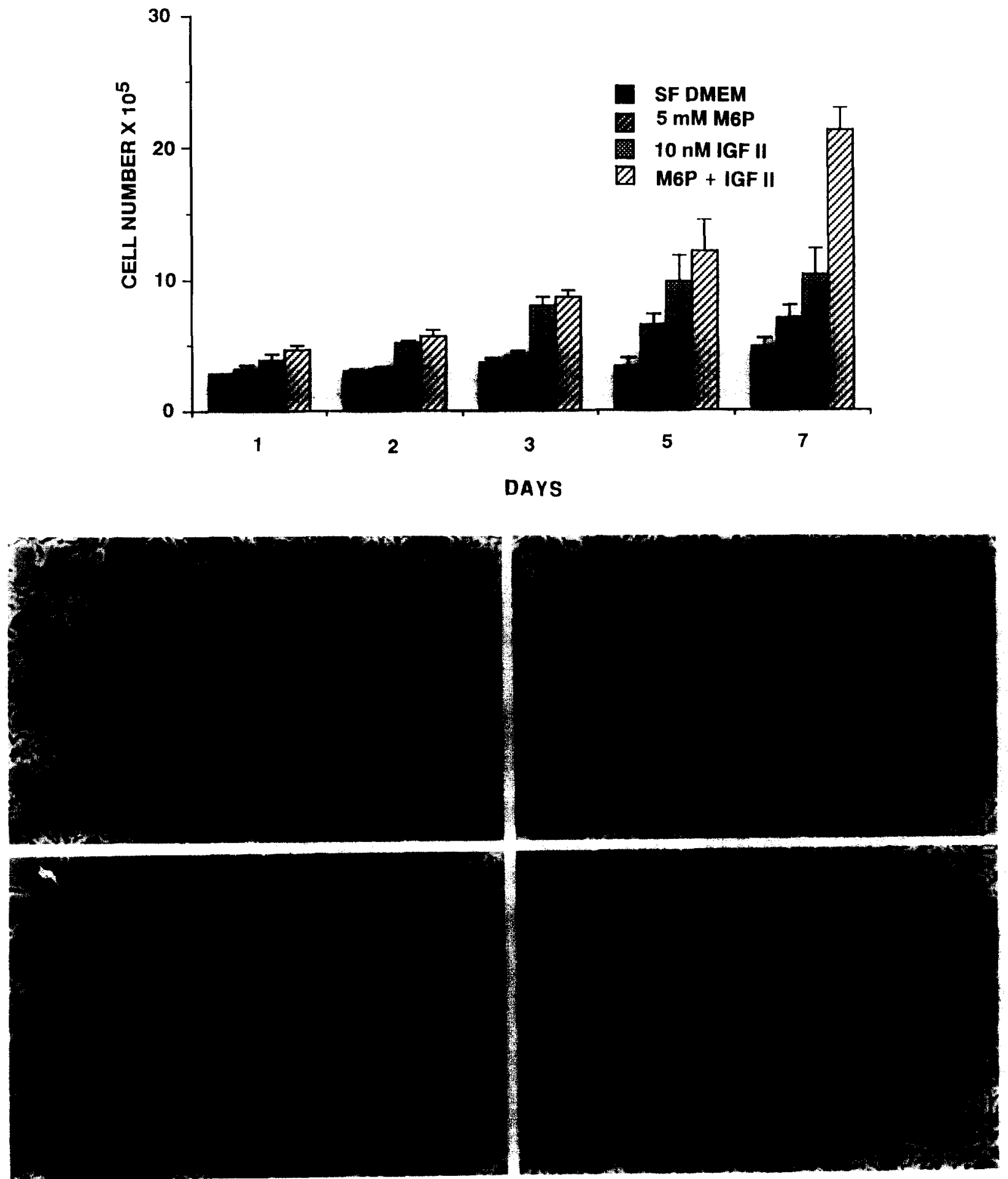

Fig. 1. Effect of man-6-P and IGF-II on SH-SY5Y neuroblastoma doubling. $3 \times 10^{5}$ cells were seeded in DMEM with $10 \%$ CS. After 3 days

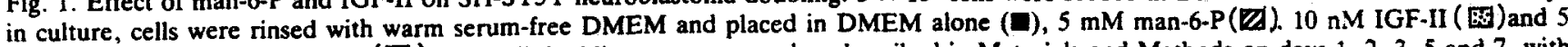
in culture, cells were rinsed with $(\square)$ Top: cell doubling was measured as described in Materials and Methods on days $1,2,3,5$ and 7, with a media change on day 4 . Values are means \pm S.E.M. of triplicate replicates, from one of 3 experiments which gave similar results. Bottom: photomicrograph of cells at day 5: A, DMEM alone ; B, $5 \mathrm{mM}$ man-6-P; C, $10 \mathrm{nM}$ IGF-II; and D, $5 \mathrm{mM}$ man-6-P plus $10 \mathrm{nM}$ IGF-II. Bar $=100 \mu \mathrm{M}$. 


\section{TABLE I}

\section{Effect of man-6-P and IGF-II on DNA content}

Cells were seeded and cultured as described in Fig. 1. At the indicated days, an aliquot of suspended cells was pelleted and DNA ( $\mu \mathrm{g}$ ) was determined as described in Materials and Methods. Results are means \pm S.E.M. of triplicate replicates, from one of 3 experiments which gave similar results.

\begin{tabular}{llllll}
\hline & \multicolumn{2}{l}{ Days } & & & \\
\cline { 2 - 6 } & \multicolumn{1}{l}{$l$} & 2 & 3 & 5 & 7 \\
\hline Man-6-P & $8.8 \pm 0.5$ & $10.9 \pm 1.7$ & $12.2 \pm 1.5$ & $12.0 \pm 1.0$ & $13.9 \pm 2.5$ \\
IGF-II & $10.0 \pm 0.9$ & $14.6 \pm 0.3$ & $17.7 \pm 1.2$ & $20.1 \pm 2.7$ & $21.2 \pm 4.6$ \\
Man-6-P + IGF-II & $11.4 \pm 0.9$ & $14.0 \pm 2.9$ & $20.4 \pm 1.3$ & $32.2 \pm 1.1$ & $50.2 \pm 8.9$ \\
\hline
\end{tabular}

taining the test agents. Each agent was tested in 3 replicate wells. A baseline cell count was obtained on the day of dosing and cell doubling was measured on days $1,2,3,5$ and 7 , with a media change on day 4. Floating and attached cells were counted. The media containing floating cells was transferred from each well to tubes, and the attached cells were incubated with $1 \mathrm{ml} 0.05 \%$ trypsin, 0.53 mM EDTA at $37^{\circ} \mathrm{C}$ for $10 \mathrm{~min}$. After terminating trypsinization with $1 \mathrm{ml} \mathrm{DMEM}$ with $10 \% \mathrm{CS}$, cells were centrifuged for $2 \mathrm{~min}$ at $1000 \mathrm{rpm}$ and the cell pellet resuspended in $0.25 \mathrm{ml}$ Hanks' balanced salt solution. A $0.1 \mathrm{ml}$ aliquot was taken and viable cells were counted in a hemocytometer using Trypan blue dye exclusion. The remaining cell suspension was centrifuged at $3000 \mathrm{rpm}$ for 2 min and the cell pellet stored at $-20^{\circ} \mathrm{C}$ for determination of cellular DNA.

\section{Neurite outgrowth ${ }^{20,23}$}

For measuring neurite outgrowth, cells were trypsinized as described above, triturated to obtain a single cell suspension and seeded into 12-well plates in $1 \mathrm{ml}$ of DMEM with $10 \% \mathrm{CS}$. After 3 days of growth to allow attachment and recovery from trypsinization, the cells were rinsed with $0.5 \mathrm{ml}$ warm serum-free DMEM before dosing with $1 \mathrm{ml}$ warm media containing the test agents. Neurite outgrowth was measured on days $1,2,3,5$ or 7 . The percentage of neurite-bearing cells was determined by counting 100 cells from randomly selected fields in each of 3 culture wells under low-power phase contrast microscopy. Cells bearing neurites of $\mathbf{4 0}$ $\mu \mathrm{m}$ or more were scored positively and cells with multiple neurites were scored only once. Partially obscured neurites caused by cell

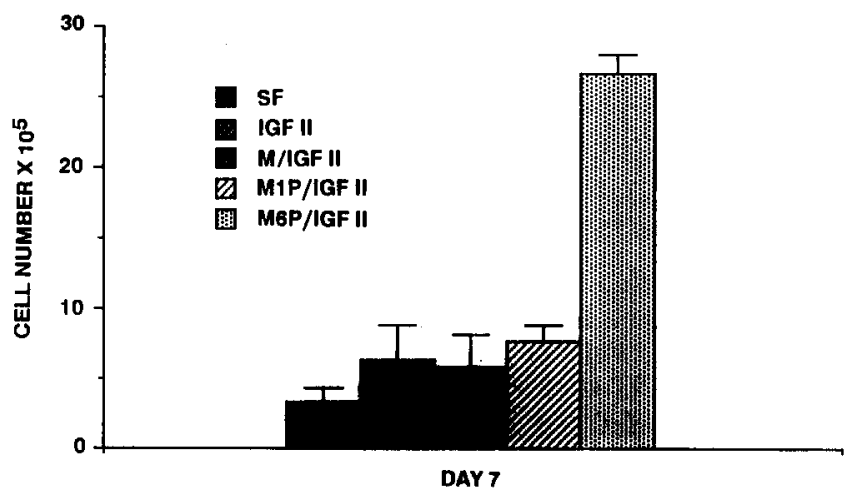

Fig. 2. Man-6-P potentiates IGF-II-stimulated neuronal doubling. $3 \times 10^{5}$ cells were seeded in DMEM with $10 \%$ CS. After 3 days in culture, cells were rinsed with warm serum-free DMEM and placed in DMEM alone ( 0 ), $10 \mathrm{nM}$ IGF-II (W) $10 \mathrm{nM}$ IGF-II plus $5 \mathrm{mM}$ mannose(图), $10 \mathrm{nM}$ IGF-II plus $5 \mathrm{mM}$ man-1-P (Q) and $10 \mathrm{nM}$ IGF-II plus $5 \mathrm{mM}$ (man-6-P ( described in Materials and Methods on day 7 , with a media change on day 4. Values are means \pm S.E.M. of triplicate replicates. clustering were not scored. Representative photographs were taken of cells in each test condition on days $1,2,3,5$ and 7 .

DNA assay ${ }^{I I}$

This method involves hydrolysis of purine nucleotides by heating, allowing the exposed sugars to react with diaminobenzoic acid (DABA). Cell pellets remaining from the cell growth study were dissolved in $0.1 \mathrm{ml}$ of $0.1 \%$ sodium dodecyl sulfate (SDS). An equal volume of decolorized, purified 1.8 $\mathrm{M}$ DABA was added to each tube. After $30 \mathrm{~min}$ at $60^{\circ} \mathrm{C}, 1.5 \mathrm{ml} 1 \mathrm{~N} \mathrm{HCl}$ was added to each tube and wavelength readings were measured in a Shimadzu spectrofluorophotometer (activation 410, emission 502). Calf thymus DNA $\left(2 \mathrm{mg} / \mathrm{ml}\right.$ in $\left.0.1 \mathrm{~N} \mathrm{NH}_{4} \mathrm{OH}\right)$ was used to generate a standard curve.

\section{RESULTS}

\section{Cell doubling}

The effects of man-6-P and IGF-II on neuronal doubling are shown in Fig. 1. In serum-free media, the cells survived for 7 days with no significant change in cell number, as previously reported by Sonnefeld and Ishii ${ }^{35}$. With the addition of $5 \mathrm{mM}$ man-6-P, cell number remained constant for the first 3 days, but after the media change on day 4 , there was a $55 \%$ increase in cell number observed on day 5 which remained constant at day 7. In the presence of $10 \mathrm{nM}$ IGF-II, cell number increased by $37 \%$ by day 2 , doubled at day 3 and then remained constant.

When cells were grown in the presence of both man6-P and IGF-II, neuronal number doubled by day 2 , tripled by day 3, increased 4-fold on day 5 and 7 -fold on day 7. The effects on neuronal growth of man-6-P and IGF-II together, when compared with each factor separately, were more than additive on day 7 . DNA determinations confirmed cell counts (Table I). These effects were specific for man-6-P and did not occur in the presence of mannose or mannose-1-P (man-1-P) (Fig. 2). Concentrations between $5 \mu \mathrm{M}$ and $5 \mathrm{mM}$ of man-6-P were not toxic to the cells (Fig. 3A) and cell death with corresponding decreases in total DNA (Fig. 3B) were observed only at concentrations equal to or greater than $10 \mathrm{mM}$ man-6-P. 
The effects of man-6-P and IGF-I on neuronal doubling are presented in Table II. There was no difference between 1,3 or $10 \mathrm{nM}$ IGF-I alone, $5 \mathrm{mM}$ man-6-P, or 1 and 3 nM IGF-I plus 5 mM man-6-P on neuronal doubling at day 7 . However, cell number more than doubled in the presence of $10 \mathrm{nM}$ IGF-I and $5 \mathrm{mM}$ man-6-P compared to each factor separately.

\section{Neurite outgrowth}

The effects of man-6-P and IGF-II on neurite outgrowth are shown in Fig. 4. In serum-free conditions, neurite formation remained stable between days 1 and 3 , averaging $35 \%$. After media change, neurite outgrowth decreased by $10 \%$ on day 5 , but returned to baseline on day 7. Man-6-P enhanced neurite outgrowth to $50 \%$ on day 1 . This effect was lost by day 2 , when neurite outgrowth decreased to $40 \%$ where it remained throughout the study. In the presence of IGF-II, neurite outgrowth
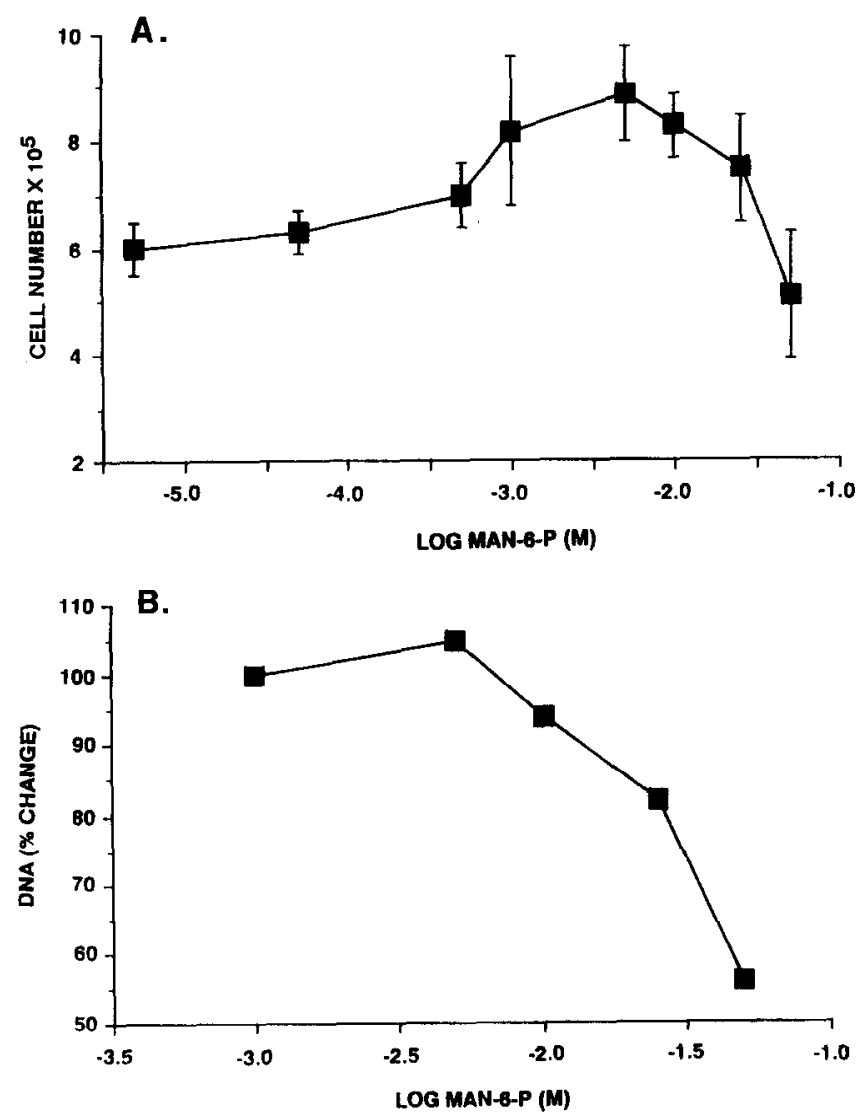

Fig. 3. Effect of man-6-P on SH-SY5Y neuroblastoma doubling. 3 $\times 10^{5}$ cells were seeded in DMEM with $10 \%$ CS. After 3 days in culture, cells were rinsed with warm serum-free DMEM and grown in DMEM plus different concentrations of man-6-P. A: cell doubling was measured as described in Materials and Methods on day 3. Values are means \pm S.E.M. of 3 replicate cultures. Cell death was first observed at $10 \mathrm{mM}$ man-6-P. B: DNA determinations were performed after the doubling measurements on each of 3 replicate cultures as described in Materials and Methods. Mean DNA values are expressed as the percent change of the average DNA value at $1 \mathrm{mM}$ man-6-P $(13.2 \pm 2.4 \mu \mathrm{g})$ designated as $100 \%$.

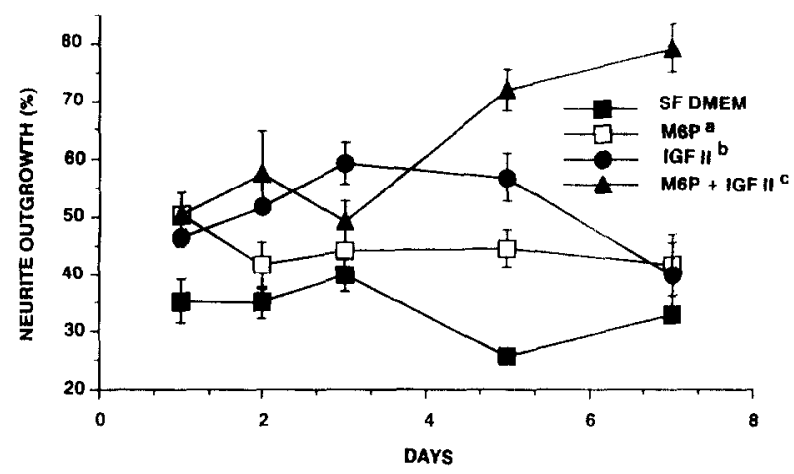

Fig. 4. Effect of man-6-P and IGF-II on SH-SY5Y neuroblastoma neurite outgrowth. $1 \times 10^{4}$ cells were seeded in DMEM with $10 \%$ CS. After 3 days in culture, cells were rinsed with warm serumfree DMEM and placed in DMEM alone ( $\square$ ), $5 \mathrm{mM}$ man-6-P ( $\square$ ), $10 \mathrm{nM}$ IGF-II (O) and $5 \mathrm{mM}$ man-6-P plus $10 \mathrm{nM}$ IGF-II (A). Neurite outgrowth was measured as described in Materials and Methods. Values are means \pm S.E.M. of triplicate results, from one of 3 experiments which gave similar results. Statistical significance was determined with the Student's $t$-test. ${ }^{a} P<0.01$ compared to SF DMEM cultures on days 1 and $5 ;{ }^{b} P<0.01$ compared to SF DMEM cultures on days $1-5 ;{ }^{c} P<0.01$ compared to SF DMEM cultures on days $1-7$.

increased linearly over time, reaching $60 \%$ by day 3 . After media change on day 4 , outgrowth on day 5 remained stable at $57 \%$, but declined to $39 \%$ on day 7 . In the presence of both man-6-P and IGF-II, neurite outgrowth averaged $50 \%$ between days 1 and 3 . After media change on day 4 , outgrowth increased to $72 \%$, and by day 7 , peaked at $80 \%$.

\section{DISCUSSION}

The man-6-P receptor is structurally and functionally identical to the receptor for IGF-II ${ }^{16,20}$, a polypeptide with mitogenic activity ${ }^{6,9,10,12,18,34}$. This multifunctional receptor, with distinct but cooperative binding sites for both man-6-P and IGF-II ${ }^{4,33}$, mediates intracellular and extracellular targeting of man-6-P-containing proteins via

\section{TABLE II}

Effect of man-6-P and IGF-I on SH-SY5Y neuroblastoma doubling

$3 \times 10^{5}$ cells were seeded in DMEM with $10 \%$ CS. After 3 days in culture, cells were rinsed with warm serum-free DMEM and placed in DMEM alone; $5 \mathrm{mM}$ man-6-P; 1,3 or $10 \mathrm{nM}$ IGF-I; and $5 \mathrm{mM}$ man-6-P plus 1,3 or $10 \mathrm{nM}$ IGF-I. Values are means $\times 10^{5} \pm$ S.E.M. of triplicate replicates, from one of two experiments which gave similar results.

\begin{tabular}{lrrr}
\hline & \multicolumn{3}{c}{ Concentration of IGF-I } \\
\cline { 2 - 4 } & \multicolumn{1}{c}{$3 n M$} & \multicolumn{1}{c}{$3 n M$} & \multicolumn{1}{c}{$10 n M$} \\
\hline Man-6-P & $8.7 \pm 0.9$ & $9.8 \pm 1.0$ & $8.0 \pm 0.6$ \\
IGF-I & $8.5 \pm 0.8$ & $12.3 \pm 1.0$ & $8.9 \pm 2.4$ \\
Man-6-P + IGF-I & $10.6 \pm 1.8$ & $12.9 \pm 0.6$ & $20.3 \pm 1.4$
\end{tabular}


the man-6-P binding site ${ }^{8}$. Transmembrane signalling of IGF-II's growth promoting effects can occur via the IGF-II binding site ${ }^{2,3,7,13.17,23,24}$. Thus, the man-6-P/ IGF-II receptor can serve as a way to integrate the dynamic function of glycoproteins with growth factor signaling and may play a key role in the life cycle of a neuron. We postulated that man-6-P might have a direct effect on neuroblastoma cells and modulate the known mitogenic $^{12,18}$ and neurite promoting ${ }^{19,27,29,30}$ effects of IGF-II on these cells.

Man-6-P alone stimulated SH-SY5Y neuroblastoma doubling in a dose-dependent fashion. At concentrations less than $5 \mu \mathrm{M}$, man-6-P had no effect on neuroblastoma doubling while concentrations equal to or greater than $10 \mathrm{mM}$ were toxic to the cells. Between $5 \mu \mathrm{M}$ and $5 \mathrm{mM}$, man-6-P enhanced neuronal doubling, while $5 \mathrm{mM}$ mannose and man-1-P had no effect. Nielsen and Gammeltoft $^{21}$ reported a similar stimulation by man-6-P of rat brain neuronal precursor cells. This stimulation was inhibited by antiserum specific for the man-6-P/IGF-II receptor. The mitogenic effect of man-6-P on neuroblastoma cells (our data) and neuronal precursor cells (ref. 21) suggests that man-6-P-containing proteins could modulate neuronal growth via the IGF-II/man-6-P receptor. Mitogenic man-6-P-containing proteins have been identified, including transforming growth factor- $\beta 1$ precursor $^{26}$ and proliferin ${ }^{14}$, which bind to the IGF II/man-6-P receptor and activate phospholipase $\mathrm{C}^{32}$. A third man6-P-containing protein is a lysosomal enzyme known as cathepsin D. Cathepsin D binds the IGF-II/man-6-P receptor, stimulates cellular growth and alters IGF-II mediated cell doubling ${ }^{17,36}$, supporting our tenet that distinct ligands can effect growth via binding to the multifunctional IGF-II/man-6-P receptor.

In agreement with Ishii and associates ${ }^{12,18,19,27,29,30}$, we found that the IGFs stimulated SH-SY5Y neuroblastoma doubling and neurite outgrowth. Our data suggests that man-6-P potentiates these IGF induced cellular responses via the IGF II/man-6-P receptor. In SH-SY5Y neuroblastoma cells, the half-maximal displacement of ${ }^{125} \mathrm{I}$-IGF-I by its unlabeled ligand is $2-5 \mathrm{nM}$ while $10 \mathrm{nM}$ IGF-I occupies over $50 \%$ of the IGF-II receptor sites ${ }^{28}$. Man-6-P did not potentiate IGF-I stimulated neuronal doubling when the growth factor was present at 1 or 3 $\mathrm{nM}$, concentrations at which IGF-I preferentially binds IGF-I receptors in neuroblastoma cells ${ }^{28}$. In contrast, at $10 \mathrm{nM}$ IGF-I, where there is significant cross-occupancy of IGF-I with the IGF-II receptor ${ }^{28}$, we observed man6-P potentiation of growth factor induced doubling. Similarly, after 7 days in culture, addition of either man-6-P or IGF-II stimulated neuronal doubling by $42 \%$ and $110 \%$, respectively. However, when added together, man-6-P and IGF-II increased cell number by $335 \%$, a response much larger than can be accounted for by a simple additive effect. In parallel, by day 7 , addition of either man-6-P or IGF-II-stimulated neurite outgrowth by approximately $30 \%$, while together, man-6-P and IGF-II enhanced outgrowth by $132 \%$.

There are other biological examples of man-6-P potentiation of signal transduction by the IGF-II/man-6-P receptor, including phospholipase $\mathrm{C}$ activation by IGF$\mathrm{II}^{31}$, transforming growth factor- $\beta 1$ precursor and proliferin $^{32}$. In these studies and in our own work, the mechanism which underlies man-6-P potentiation is not determined, but several possibilities exist. Potentiation could result from a man-6-P enhancement of available man-6-P/IGF-II cell surface receptors. In our studies, the effects of man-6-P were most pronounced in cells which had been in culture for 5 or more days, suggesting increased receptor availability over time. This phenomenon is reported in fibroblasts, where binding of man-6-P to the IGF-II/man-6-P receptor triggers redistribution of the receptor to the cell surface, increasing available ligand binding sites ${ }^{5}$. Alternatively, man-6-P may directly enhance IGF-II binding by displacing inhibitory ligands ${ }^{25}$ or increasing the affinity of IGF-II for its receptor $^{33}$. While these explanations remain plausible for our studies, they cannot explain the mechanism of man6-P-potentiated IGF-II phospholipase $\mathrm{C}$ activation in the kidney, reported by Rogers and Hammerman ${ }^{31}$. In this model, man-6-P-potentiated IGF-II induced phospholipase $\mathrm{C}$ activation by $215 \%$ while specific IGF-II binding was increased by only $26 \%$. Furthermore, man-6-P decreased transforming growth factor- $\beta 1$ precursor and proliferin binding to the IGF-II/man-6-P receptor, but potentiated peptide stimulated renal phospholipase $\mathrm{C}$ activation $^{32}$. It is possible that potentiation of phospholipase C activity (Hammerman's studies) and of neuroblastoma doubling and neuritic outgrowth (our studies) reflects an action of man-6-P to directly enhance IGF-II signal transduction. Further studies are needed to address these issues.

In summary, the IGF-II/man-6-P receptor is a multifunctional protein capable of binding both IGF-II and man-6-P $\mathbf{P}^{16,20}$. In human cultured neuroblastoma cells, man-6-P stimulated mitogenesis and neurite outgrowth and potentiated the known growth promoting effects of IGF-II. We speculate that the IGF-II/man-6-P receptor can serve as a way to integrate signaling from glycoproteins, including man-6-P containing growth factors, and IGF-II in neuronal cells.

Acknowledgements. This work was supported by NIH Grant NS01381 to E.L.F. We would like to express our sincere appreciation to Sally Lattimer Greene for instruction in the DNA assays, and to Drs. Douglas Greene and Anne Heacock for helpful discussions. 


\section{REFERENCES}

1 Balasubramanian, A.S., Minireview: phosphomannose binding proteins: the phosphomannosyl receptor and insulin like growth factor II receptor, Life Sci., 43 (1988) 1953-1959.

2 Ballard, F.J., Read, L.C., Francis, G.L., Bagley, C.J. and Wallace, J.C., Binding properties and biological potencies of insulin-like growth factors in L6 myoblasts, Biochem. J., 233 (1986) 223-230.

3 Blanchard, M.M., Barenton, B., Sullivan, A., Foster, B., Guyda, H.J. and Posner, B.I., Characterization of the insulinlike growth factor (IGF) receptor in K562 erythroleukemia cells; evidence for a biological function for the type II IGF receptor, Mol. Cell Endocrinol., 56 (1988) 235-244.

4 Braulke, T., Causin, C., Waheed, A., Junghaus, U., Hasilik, A., Maly, P., Humbel, R.E. and von Figura, K., Mannose 6-phosphate/insulin-like growth factor II receptor: distinct binding sites for mannose 6-phosphate and insulin-like growth factor II, Biochem. Biophys. Res. Commun., 150 (1988) 1287-1293.

5 Braulke, T., Tippmer, S., Neher, E. and von Figura, K., Regulation of the mannose 6-phosphate/IGF II receptor expression at the cell surface by mannose 6-phosphate, insulin like growth factors and epidermal growth factor, EMBO J., 8 (1989) 681-686.

6 Clemmons, D.R., Structural and functional analysis of insulinlike growth factors, Br. Med. Bull., 45 (1980) 465-480.

7 Czech, M.P., Signal transmission by the insulin-like growth factors, Cell, 59 (1989) 235-238.

8 Dahms, N.M., Lobel, P. and Kornfeld, S., Mannose 6-phosphate receptors and lysosomal enzyme targeting, J. Biol. Chem., 264 (1989) 12115-12118.

9 Daughaday, W.H. and Rotwein, P., Insulin-like growth factors I and II. Peptide, messenger ribonucleic acid and gene structures, serum, and tissue concentrations, Endocrinol. Rev., 10 (1989) 68-91.

10 El-Badry, O.M., Romanus, J.A., Helman, L.J., Cooper, M.J., Rechler, M.M. and Israel, M.A., Autonomous growth of a human neuroblastoma cell line is mediated by insulin-like growth factor II, J. Clin. Invest., 84 (1989) 829-839.

11 Hinegardner, K.'T., An improved fluorometric assay for DNA, Anal. Biochem., 39 (1971) 197-201.

12 Ishii, D.N., Recio-Pinto, E., Spinelli, W., Mill, J.F. and Sonnenfeld, K.H., Neurite formation modulated by nerve growth factor, insulin, and tumor promoter receptors, Int. J. Neurosci. 26 (1985) 109-127.

13 Kiess, W., Haskell, J.F., Lee, L., Greenstein, L.A., Miller, B.E. Aarons, A.L., Rechler, M.M. and Nissley, S.P., An antibody that blocks insulin-like growth factor (IGF) binding to the type II IGF receptor is neither an agonist nor an inhibitor of IGF-stimulated biologic responses in L6 myoblasts, $J$. Biol. Chem., 262 (1987) 12745-12751.

14 Lee, S.-J. and Nathan, D., Proliferin secreted by cultured cells binds to mannose 6-phosphate receptors, J. Biol. Chem., 263 (1988) 3521-3527.

15 Lobel, P., Dahms, N.M., Breitmeyer, J., Chirgwin, J.M. and Kornfeld, S., Cloning of the bovine 215-kDa cation-independent mannose 6-phosphate receptor, Proc. Natl. Acad. Sci. U.S.A., 84 (1987) 2233-2237.

16 MacDonald, R.G., Pfeffer, S.R., Coussens, L., Tepper, M.A., Brocklebank, C.M., Mole, J.E., Anderson, J.K., Chen, E., Czech, M.P. and Ullrich, A., A single receptor binds both insulin-like growth factor II and mannose-6-phosphate, Science, 239 (1988) 1134-1137.

17 Mathieu, M., Rochefort, H., Barenton, B., Prebois, C. and Vignon. F.. Interactions of cathepsin-D and insulin-like growth factor-II (IGF-II) on the IGF-II/mannose-6-phosphate receptor in human breast cancer cells and possible consequences on mitogenic activity of IGF-II, Mol. Endocrinol., 4 (1990) 13271335.

18 Mattsson, M.E.K., Enberg, G., Ruusala, A.-I., Hall, K. and Pahlman, S., Mitogenic response of human SH-SY5Y neuroblastoma cells to insulin-like growth factor I and II is dependent on the stage of differentiation, J. Cell Biol., 102 (1986) $1949-1954$
19 Mill, J.F., Chao, M.V. and Ishii, D.N., Insulin, insulin-like growth factor II, and nerve growth factor effects on tubulin mRNA levels and neurite formation, Proc. Natl. Acad. Sci. U.S.A., 82 (1985) 7126-7130.

20 Morgan, D.O., Edman, J.C., Standring, D.N., Fried, V.A. Smith, M.C., Roth, R.A. and Rutter, W.J., Insulin-like growth factor II receptor as a multifunctional binding protein, Nature, 329 (1987) 301-307

21 Nielsen, F.C. and Gammeltoft, S., Mannose-6-phosphate stimulates proliferation of neuronal precursor cells, FEBS Lett., 262 (1990) 142-144.

22 Obberghen-Schilling, E.V. and Pouyssegur, J., Mitogen-potentiating action and binding characteristics of insulin and insulinlike growth factors in Chinese hamster fibroblasts, Exp. Cell Res., 147 (1983) 369-378.

23 Okamoto, T., Katada, T., Murayama, Y., Ui, M., Ogata, E. and Nishimoto, I., A simple structure encodes $G$ protein-activating function of the IGF-II/mannose 6-phosphate receptor, Cell, 62 (1990) 709-717.

24 Okamoto, T., Nishimoto, I., Murayama, Y., Ohkumi, Y. and Ogata, E., Insulin-like growth factor-II/mannose 6-phosphate receptor is incapable of activating GTP-binding proteins in response to mannose 6-phosphate, but capable in response to insulin-like growth factor-II, Biochem. Biophys. Res. Commun., 168 (1990) 1201-1210.

25 Polychronakos, C., Guyda, H.J. and Posner, B.I., Mannose 6-phosphate increases the affinity of its cation-independent receptor for insulin-like growth factor II by displacing inhibitory endogenous ligands, Biochem. Biophys. Res. Commun., 157 (1988) 632-638.

26 Purchio, A.F., Cooper, J.A., Brunner, A.M., Lioubin, M.N. Gentry, L.E., Kovacina, K.S., Roth, R.A. and Marquardt, H., Identification of mannose-6-phosphate in two asparagine-linked sugar chains of recombinant transforming growth factor- $\beta 1$ precursor, J. Biol. Chem., 263 (1988) 14211-14215.

27 Recio-Pinto, E. and Ishii, D.N., Effects of insulin, insulin-like growth factor-II and nerve growth factor on neurite outgrowth in cultured human neuroblastoma cells, Brain Research, 302 (1984) 323-334.

28 Recio-Pinto, E. and Ishii, D.N., Insulin and insulin-like growth factor receptors regulating neurite formation in cultured human neuroblastoma cells, J. Neurosci. Res., 19 (1988) 312-320.

29 Recio-Pinto, E., Lang, F.F. and Ishii, D.N., Insulin and insulin-like growth factor II permit nerve growth factor binding and the neurite formation response in cultured human neuroblastoma cells, Proc. Natl. Acad. Sci. U.S.A., 81 (1984) 2562-2566.

30 Recio-Pinto, E., Rechler, M.M. and Ishii, D.N., Effects of insulin, insulin-like growth factor II, and nerve growth factor on neurite formation and survival in cultured sympathetic and sensory neurons, $J$. Neurosci., 6 (1986) 1211-1219.

31 Rogers, S.A. and Hammerman, M.R., Mannose 6-phosphate potentiates insulin-like growth factor II-stimulated inositol trisphosphate production in proximal tubular basolateral membranes, J. Biol. Chem., 264 (1989) 4273-4276.

32 Rogers, S.A., Purchio, A.F. and Hammerman, M.R., Mannose 6-phosphate-containing peptides activate phospholipase $\mathrm{C}$ in proximal tubular basolateral membranes from canine kidney, $J$. Biol. Chem., 265 (1990) 9722-9727.

33 Roth, R.A., Stover, C., Hari, J., Morgan, D.O., Smith, M.C., Sara, V. and Fried, V.A., Interactions of the receptor for insulin-like growth factor II with mannose-6-phosphate and antibodies to the mannose-6-phosphatc receptor, Biochem. Biophys. Res. Commun., 149 (1987) 600-606.

34 Sara, V.R. and Hall, K., Insulin-like growth factors and their binding proteins, Physiol. Rev., 70 (1990) 591-614.

35 Sonnefeld, K.H. and Ishii, D.N., Nerve growth factor effects and receptors in cultured human neuroblastoma cell lines, $J$. Neurosci. Res., 8 (1982) 375-391.

36 Vignon, F., Capony, F., Chambon, M., Freiss, G., Garcia, M. and Rochefort, H., Autocrine growth stimulation of the MCF 7 breast cancer cells by the estrogen-regulated $52 \mathrm{~K}$ protein, Endocrinology, 118 (1986) 1537-1545. 